Vol. 2, No. 2, December 2021: p. 103-121. DOI: 10.18326/islah.v2i2.103-121

ISSN : 2723-407X

Website: https://e-journal.iainsalatiga.ac.id/index.php/islah

\title{
Factors of Muslim Fashion Progress in Surakarta City: A History Review
}

\author{
Laela Puji Utami \\ Pondok Pesantren Darussalam Ngesong, Sengon, Jombang \\ hidrogensi@gmail.com
}

$\begin{array}{ll}\text { Submission Track: } & \\ \text { Received } & : 2021-07-15 \\ \text { Final Revision } & : 2021-10-15 \\ \text { Available Online } & : 2021-12-01\end{array}$

\begin{abstract}
Nowadays, Muslim fashion is worn not only to fulfil Islamic sharia, but also to present Muslim fashion without ignoring the beauty of the fashion itself. Therefore, in its progress, Muslim fashion comes with varied, trendy and fashionable items. Examining Muslim fashion progress in Surakarta City, the researcher tries to find out the background of Muslim fashion widely known of Muslim in Surakarta City and factors causing the rapid progress of Muslim fashion in Surakarta City. This study uses historical method by using procedures in accordance with the rules and the regulations of historical writing. The findings shows that Muslim fashion in Surakarta City is influenced by some factors including: (1) the occurrence of Islamization during The New Order era in Surakarta City; (2) the entry of Ikhwanul Muslimin Thought and the occurrence of Iranian Revolution; (3) the variation of Islamic colours in Surakarta city including traditionalist, puritans, modernist, and radical; (4) the high number of middle class Muslims with a consumptive lifestyle; (5) the history of Surakarta City as the birthplace of Serikat Dagang Islam (SDI) and batik textile producer in Indonesia; (6) the existence of shopping centres, fashion houses, boutiques, and Muslim fashion shops; (7) the existence of Solo Hijabs Community in introducing and promoting Muslim fashion; and (8) the role of Ikatan Perancang Busana Surakarta (IKAPERSTA), a fashion designers association in Surakarta city, representing activities related to fashion in Surakarta City
\end{abstract}

Keywords: Progress, Muslim Fashion, Surakarta City

\begin{abstract}
Abstrak
Dewasa ini, busana muslimah dikenakan tidak hanya semata untuk memenuhi syariat agama Islam, tetapi para muslimah mencoba menghadirkan busana muslimah tanpa mengabaikan unsur keindahan dalam berbusana. Oleh sebab itu dalam perkembangannya busana muslimah hadir dengan fashion yang beragam, trendi, dan fashionable. Penelitian ini mengkaji mengenai perkembangan busana muslimah di Kota Surakarta, diantaranya peneliti berusaha menjawab mengenai latar belakang busana muslimah dikenal luas oleh muslimah Kota Surakarta dan faktor-faktor yang menyebabkan busana muslimah di Kota Surakarta mengalami perkembangan yang sangat pesat sehingga banyak diminati oleh Muslimah Kota
\end{abstract}


Surakarta. Metode yang digunakan dalam penelitian ini ialah metode sejarah dengan menggunakan prosedur sesuai dengan kaidah dan aturan penulisan sejarah. Temuan penelitian ini ialah perkembangan busana muslimah di Kota Surakarta dipengaruhi beberapa faktor: (1) Terjadinya islamisasi pada masa Orde Baru di Kota Surakarta. (2)Masuknya Pemikiran Ikhwanul Muslimin dan terjadinya Revolusi Iran. (3) Kota Surakarta yang memiliki corak warna Islam yang beragam baik itu yang bersifat tradisionalis, puritanis, modernis, dan radikalis. (4) Tingginya jumlah muslim kelas menengah dengan gaya hidup yang konsumtif. (5) Sejarah Kota Surakarta sebagai wilayah lahirnya SDI (sarikat Dagang Islam) dan penghasil tekstil batik di Indonesia. (6) Banyak dijumpai shopping center, rumah mode, butik, dan toko-toko busana muslimah. (7) Keberadaan komunitas Solo Hijabers dalam mengenalkan dan memboomingkan busana muslimah. (8) Peranan Ikapersata (Ikatan Perancang Busana Surakarta) yang menyajikan kegiatan-kegiatan seputar fashion di Kota Surakarta.

Keyword: Perkembangan, Busana Muslimah, Kota Surakarta

\section{INTRODUCTION}

Nowadays, Muslim fashion is not worn only to fulfill Islamic religious sharia. Apart from being a means of covering the body, Muslim fashion is currently present without leaving the element of beauty in fashion representing varied, trendy and fashionable Muslim fashion. Muslim fashion is also a symbol to show social class. When we look around, subconsciously we realize that many Muslim women wear Muslim fashion. The use of Muslim fashion does not only relate to religious places and events such as mosques, recitations, Eid al-Fitr, etc. However, at present, Muslim fashion becomes everyday wears and a lifestyle for Muslim. It comes with various forms, creations, colors, and types. In contrast, back in the 1980s, it was simple, perfunctory, and out of date in the form of kebaya with a veil or scarf placed on Muslim women's head.

The advance of technology and era affect the progress of Muslim fashion. Initially, Muslim fashion was simple, perfunctory, and out of date with dark colors nuance. Currently, it develops into a fashionable, feminie and elegant one. The varied pattern, nowadays, succeed in attracting Muslim women to wear Muslim fashion. Those wears can be modified based on individual style. The fashion world is changing very quickly including Muslim fashion, which become a trend and increase Muslim women interest in fashion in Islamic way. ${ }^{1}$

\footnotetext{
${ }^{1}$ Nuraini, "Potensi Kiblat Mode Muslim Dunia", Majalah Warta Exspor Industri Muslim 2015, (Jakarta, Kementrian Perdagangan Republik Indonesia, 2015)., pp.4-6
} 
In this study, the researchers examine the progress of Muslim fashion in Surakarta City. This research refers to trace how Muslim women in Surakarta city were initially familiar with Muslim fashion as a must-wear fashion. This study explains about Muslim fashion's advance from a simple, traditional wears with plain colors and a veil into an up-todate, trendy and fashionable fashion. The role of Islamization events during the New Order era in Surakarta city become a starting point which result in the massive use of Muslim fashion as an implementation or symbolic evidence of Muslim. The number of Muslim people in Surakarta City shows a high percentage. In 2018, there was a record showing that the population of Muslim was 447.584 or over $78.56 \% .^{2}$ In addition, Surakarta city has various pattern of Islam including traditional, puritanical, modern, and radical. As the birthplace of Sarekat Dagang Islam (SDI) and the place where Kampung Batik Laweyan located, it indicates that most people work as traders and entrepreneurs. Moreover, the main mover of economy sector in Surakarta city is the small and medium industry. The batik and textile production industry are prominent in Surakarta city seen from the amount of production and investment value. ${ }^{3}$ It is concluded that the purpose of this study is to find out the background of Muslim fashion widely known of Muslim in Surakarta City and factors causing the rapid progress of Muslim fashion in Surakarta City.

Some references are used in this study including Hanung Sito Rohmawati's work entitled "Busana Muslimah dan Dinamikanya di Indonesia" which is published in Al-Aqlam journal discussing the phenomenon of Muslim Fashion in Indonesia. ${ }^{4}$ This paper wants to show that Muslim fashion as a symbol or religiosity for those who wear it. Specifically, the writer discusses how the progress of Muslim fashion in Surakarta city. Moreover, in this study the writer emphasizes the historical aspect of it. An article published in SUHUF Journal $^{5}$ written by Chusniatun is entitled "Perhatian Kaum Muslim Terhadap Busana Muslim". She concludes that the emergence of special attention by Muslim of Muslim fashion in Surakarta starts at 1980s when many young Muslim women learned Islam. In addition, they also want to apply it to everyday life as fashion distinguish themselves from

\footnotetext{
${ }^{2}$ Dinas Kependudukan dan Pencatatan Sipil Kota Surakarta, “Profil Perkembangan Kependudukan Kota Surakarta Tahun 2018,, p.45

${ }^{3}$ Daryono Soebagiyo dan M. Wahyudi, “Analisis Kompetensi Produk Unggulan Daerah Pada Batik Tulis dan Cap Solo Di Dati 11 Kota Surakarta”, Jurnal Ekonomi Pembangunan, Vol.9, No.2, 2008., p.189

${ }^{4}$ Hanung Sito Rohmawati, "Busana Muslimah dan Dinamikanya di Indonesia", Jurnal Al-Aqlam, journal of Islam and Plurality, Vol. 5, No. 1, 2020.

${ }^{5}$ Chusniatun, "Perhatian Kaum Muslim Terhadap Busana Muslim" Jurnal SUHUF, Vol.22, No.1, Mei 2010 , p.87
} 
other groups or people. The article is quite similar to this study as both studies examine Surakarta city and Muslim fashion. However, there are few things that make those researches different. In this research, the writer specifically discusses about Muslim fashion and factors causing the rapid progress of Muslim fashion in Surakarta City. In addition, the writer also uses historical research method.

\section{METHODOLOGY}

This study uses historical research methods which met the research rules. The method has a systematic set of rules and principles for collecting sources and evaluating the sources critically. This method is as a form of implementation and technical material, criticism and interpretation of the history as well as in the report. There are some stages in this research including heuristics (collecting sources) and verification (criticizing sources internally and externally) - in this stage, the researcher re-assures the sources obtained such as newspapers or magazines by checking the physical form of the sources (paper and ink) and selecting the sources according to the theme and its originality in accordance with the conditions, and compares the interview result and the written sources (newspaper) for resulting an equivalence statements - interpretation (by doing analysis (decomposition) and synthesis (unification)), and historiography (writing history). ${ }^{6}$

Primary sources used as references in this study include document sources in the form of articles or photos contained in local newspapers or magazines in Surakarta city representing the progress of Muslim fashion in Surakarta city. Some local newspaper in Surakarta city also become sources, namely Radar Solo, Solo Pos, Suara Bengawan, ADIL newspaper. The researcher also conducted interviews who provide relevant information including Mrs. Tini, Mrs. Yuliana, and Mrs. Esty who represent Muslim women in Surakarta city, Mrs. Dian who represent as Solo Hijabers Community, some businessmen of Muslim fashion in Surakarta, namely Bilqis Boutique and Al-Fath Boutique.

\footnotetext{
${ }^{6}$ A Daliman, "Metodologi Penelitian Sejarah", (Yogyakarta, Penerbit Ombak: 2021)., p.54
} 


\section{DISCUSSION}

\section{The Background of Muslim Fashion widely known by Muslim woman in Surakarta City}

\section{Islamization in Surakarta city during New Order Era}

Islamization in Surakarta city cannot be separated from the socical-political conditions of Surakarta people at that time. There was one major event called G30S/PKI which result Islamization in Surakarta. This incident led to chaos resulting upheaval among communities. Basically, Surakarta city was one of strong base of PKI at the end of Soekarno period. In order to restore the condition, after G30S/PKI incident, restoration was carried out through some political actions. Religion was also used as an instrument to restore security. It was carried out by military through indoctrination activities against political prisoners from PKI or those who were doctrine as $\mathrm{PKI}^{7}$

The impact of G30S/PKI incident in Surakarta city was seen through the number of followers of Aliran Kebatinan who decide to convert to religions recognized by government against accusations that they do not have religions or even communis. Aliran Kebatinan or other non-orthodox belief was listed in coloumn "other". In population censuses in 1974 and 1975, 19.517 people converted to "other" category which indicate that they converted to Christianity and Islam. It was recorded that the number of Muslim increased in 1974 with 334.889 people and in 1975 with 340.496 people. $^{8}$

The phenomenon occurred at the beginning of New Order era showed that the majority of Javanese people become Muslim and act within the framework of Islamic thought. In those group, Islamiation offers a template for determining a new harmony parameter of a village. Islamization is seen attractive for offering much-needed reassurance and comforting them after G30S/PKI incident. A deeper process of Islamization was encouraged by various religious organization for the sake of a "piety" agenda and supported by the government in which there were some people voluntarily convert the religions for realizing a new harmony village. ${ }^{9}$ The Islamization process was supported by the government by providing facilities for Muslim. The government launched Proyek Pembinaan Mental Agama (P2A) aimed to develop communities. P2A

\footnotetext{
7 Adif Fahrizal, "Bulan Bintang dan Salib di Kota Bengawan, Islamisasi, Kristenisasi, dan Hubungan Muslim-Kristen di Surakarta (1966-2000)”, Thesis (Yogyakarta, Universitas Gadjah Mada: 2015)., p.63

${ }^{8}$ M.C Ricklefs, “Mengislamkan Jawa”, trans. FX Dono Sunardi \& Santrio Wahono, (Jakarta, Serambi Ilmu Semesta: 2013), p. 235

${ }^{9}$ Ibid., p. 267
} 
aimed to increase the religious level of Muslim, and leaders of NU and Muhammadiyah are asked to help the program. The Five-Year Progress Plan (Pelita) allocated funds for construction mosques. In Central Java, the number of mosques increased from 15.865 in 1980 to 28.758 in 1972 . Furthermore, the government also established the first Islamic Bank in Indonesia called Bank Muammalat Indonesia. ${ }^{10}$

Besides, at that time, there was also a process of spreading Islam for directing Muslim lives to be more in line with Islamic teachings. After G30S/PKI incident, many Islamic activists took advantage of this momentum. The process of Islamization supported by the government shows the increasing level of piety in society due to the competition between the government and religious parties to rebuild and control the spirituality of Javanese people. The unique fact shows that Islam, at that moment, was not only dominated by one Islamic group or organization. The intense effort of Islamization is increasingly visible with the number of recitations held in Surakarta city. Those activities were mostly initiated by modernists. ${ }^{11}$ Pesantren Jamsaren plays a central role as the leader, Kyai Jamaluddin was a person with more-modernist thought relying on reason and mind in understanding revelation in Islam. There were also three actors behind that movement in Surakarta city in the 1970 s to 1980 s which established new schools. The actors use "Abdullah" as their first name, namely Abdullah Marzuki, Abdullah Thufail, and Abdulah Sungkar. Those three figures exemplify the diversity of ideologies and aspirations in the Javanese Islamic world, even showing the diversity of ethnic background originating from Java, Pakistan, and Arabia. ${ }^{12}$

2. The Spread of Ikhwanul Muslimin Thoughts and the Iranian Revolution

During the New Order era, the seeds of campus propaganda that were ideological in nature began to emerge. The adopted ideas are from Transnational organization such as Ikhwanul Muslimin and Hizbut Tahrir. Both ideas are strengthened in campus through Lembaga Dakwah Kampus (LDK) which was initiated by Dewan Dakwah Islam Indonesia (DDII). Students in Universitas Sebelas Maret (UNS) are one who are affected by their thought. The method used to recruit members is to approach high school student by coaching them to enter their favorite universities. The cadre is also carried out outside

\footnotetext{
${ }^{10}$ Ibid., p. 266

${ }^{11}$ Ibid., p. 300

12 Ibid., p.302
} 
campus in the form of coaching using rented house or boarding house. The domination of Ikhwanul Muslimin on UNS mosque is due to the selection of preachers in the campus environment. ${ }^{13}$ The Hijab "Islamization" movement is a movement that is quite intensively carried out among students or in the campus realm. In regeneration, one method used is done by Ikhwanul Muslimin which is strong among their followers. Their way is to classify between them and us. ${ }^{14}$

The occurrence of Islamic revival or Iranian Revolution in 1979 also had an impact in Indonesia. The influence towards Indonesia is seen through religion, politics, social, and culture sectors. One example is the widespread use of hijab at schools before the issuance of SK 052/D/Kep/C/1982 implying prohibition of wearing hijab at schools. After 10 years causing inconvenience, the regulation was reviewed and renewed. The regulation was replaced with SK 100/D/Kep/C/1991 concerning the permissibility of wearing hijab at schools. After that, in line with the improvement of New Order's relation with Islam, it impacted on Muslims' freedom of expression. Both religious activities and symbols are increasingly used for showing identity. Islamic identity is then described in the form of materialism symbolized through commodifying lifestyle resulting popular culture which later became lifestyle of Muslim in Indonesia. It is due to the fact that Muslim fashion in Indonesia was kebaya with a veil which did not perform Indonesian culture.

3. The issuance of SK $100 / \mathrm{D} / \mathrm{Kep} / \mathrm{C} / 1991$ concerning the permissibility of wearing hijab at schools for Muslim women student

The unstable relationship between Islamic politics and New Order government experienced an on-and-off cycle. The assumption that Islamic politics may take over the government resulted unfair political policies for Muslims in Indonesia. ${ }^{15}$ The government was afraid that Islam became a threat causing destabilization of political life.

The policies on New Order's era which was seen to marginalize Islam began to change in the 1980s. The government began to make an accommodative relation with Muslims. This happened because the government had previously received strong pressure and responsive reactions from Muslims related to policies that openly harass Muslims

${ }^{13}$ Arif Wibowo, presented on Guest Lecture : "Gerakan Dakwah Kampus di Universitas Sebelas Maret Surakarta", on 29 November 2018.

${ }^{14}$ Pocut Hanifah, (28 desember 2015), Fenomena Jilbab, accessed on Islamlib.com on 7 Desember 2019.

${ }^{15}$ Darmawijaya, "Islam dan Orde Baru: Membaca Kembali Politik de-Islamisasi Soeharto", Sosiologi Reflektif, Vol. 10, No.1, November 2015, p 68. 
such as gambling policies, hijab issues, Porkas, and SDSB triggering a big conflict. In addition, the government saw that there was a shift in Muslim view in accepting Pancasila as the sole principle. ${ }^{16}$

The Decree SK 100/D/Kep/C/1991 discusses the legalization of Muslim students with their personal beliefs to wear typical school uniforms or hijab at school. The difference is also on the hijab. While Muslim students wore destar or blangkon as the old typical hijab, they wear a white veil as the newest hijab. For skirts and blouses, the students wore a suit-form blouse, long-sleeves shirt (not tucked into the skirt), and knee-lengths skirt. Meanwhile, based on the new decree, the student wear a regular-shape blouse, wristlength with a flap pocket on the left shirt (tucked into a skirt), and ankles-lengths skirt. The school principal is in charge for their school. ${ }^{17}$

\section{The Progress of Muslim Fashion in Surakarta City}

After the explanation above, it can be seen that there are factors causing Muslim fashion widely known by Muslim women in Surakarta city. In this discussion, we discuss the progress of Muslim fashion in Surakarta city who was used to wear a simple and out-to-date fashion identical with kebaya with a draped-over-head veil. Today, Muslim fashion is varied in creations, shapes, models, and materials. Muslim women in Surakarta now tends to choose an up to date, fashionable and trendy fashion. For example, it is displayed by Al-Fath Boutique with Family-theme fashion, and Bilqis Boutique with classic elegant-theme fashion. Furthermore, the existence of Solo Hijabers Association, Ikapersata (Ikatan Perancang Busana Surakarta), and the expanse of shopping centers, boutiques and Muslim fashion stores help introducing Muslim fashion in Surakarta city.

Talking about Muslim women fashion in Surakarta, it become popular around the end of the 1970 s to the early 1980s. A new Islamic group plays a role in introducing hijab among Muslim in Surakarta city. Students have an important role in introducing hijab among Muslim women in Surakarta. ${ }^{18}$ This movement is an Islamic movement extending from campuses which later pioneered and influenced the process of the hijab campaign among Muslim female students. Symbolically, the movement can be interpreted as an effort to

\footnotetext{
${ }^{16}$ Faryda Ruslan, "Politik Hukum Islam Masa Orde Baru Dan Produk Perundang-Undangannya", Al Qisthas: Jurnal Hukum dan Politik, Vol.10, No.2, 2019, p.61

${ }^{17}$ Kompas, "Resmi Berlaku, Penggunaan Seragam Khas di Sekolah", edisi 17 Februari 1991, p.1

${ }^{18}$ Adif Fahrizal, "Bulan Bintang dan Salib di Kota Bengawan..., p.105
} 
identify someone in the midst of an identity crisis. ${ }^{19}$ The interest of fashion in Surakarta City can be seen from the fashion industry in Surakarta City, depicted in some activities including one done by Studio Model Agency (formerly the Fashion Model Agency) which held the election of Putra Putri Busana Muslim $1999 .^{20}$ Besides, the fashion-themed activities can be seen from activities at the Great Mosque of Surakarta such as a Muslimah fashion show competition for kindergarten and elementary schools throughout the Solo City Region. The participants of this competition won the trophy of the Chairman of Bhayangkari Polwil Surakarta.

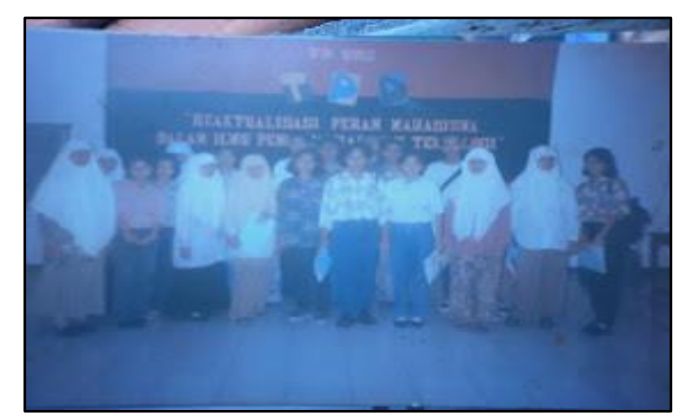

Figure 1. The Scientific Study Group,

Faculty of Agriculture, UNS, 1996.

Source: Tri Harjanto, "Archive of KSI FP

UNS Activities in the 1990s"

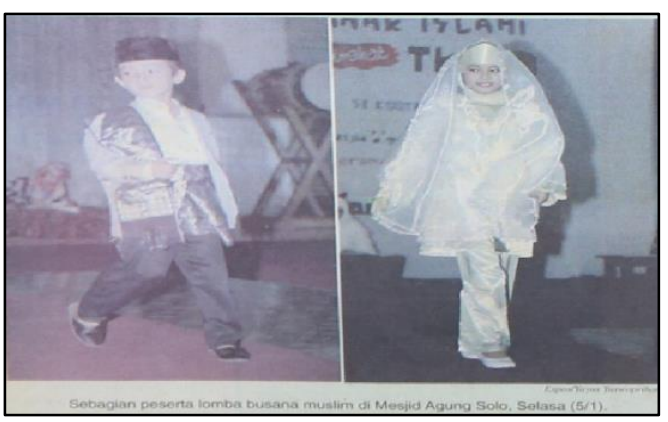

Figure 2. Participants in Muslimah fashion show in kindergarten and elementary school in Solo Source: Solo Pos, January $5^{\text {th }}, 1999$

Socio-religious activities in Surakarta city make Muslim fashion such a common thing and a habit (lifestyle). For instance, the emergence of Muslim communities and recitation activities are dominated by middle class of Muslims. Muslim community and sermon do not only enliven Islamic studies, but also help to introduce Muslim fashion among Muslim women in Surakarta City. There are many sermons in Surakarta City. The sermon as a part of the Surakarta Muslimah Council participated in halal bi halal in 2015 at the Graha Saba Buana Hotel which was attended by the First Lady of Indonesia. The seven sermon that attended were Khairunnisa, Hijaber's Mom Community, Mutiara Bening Hati, Jamiatul Al Khoir, Qonita, Sahaja, and Ekspensa. ${ }^{21}$ Technological advances also play an important role

19 Septa Kesuma, Jilbab dan Reproduksi Identitas Mahasiswi Muslimah di Ruang Publik, MUKADIMAH : Jurnal Pendidikan, Sejarah, dan Ilmu-ilmu Sosial, Vol.1, No. 2, Februari 2018., p. 140.

${ }^{20}$ Solo Pos, "Mesjid Agung \& Studio Model gelar Lomba Busana Muslim (Perebutkan Trofi Ketua Bhayangkari)", edisi 5 Januari 1999, p.12

${ }^{21}$ Solo Pos, "Aktivitas Ibu Negara: Didampingi kahiyang dan Selvi, Iriana Jokowi Hadiri Halal Bi Halal Muslimah Solo", 4 September 2015. 
in introducing the development of Muslim fashion in Surakarta city. It includes both printed media that specifically discusses the lifestyle of Muslim women and mass media that introduces hijab fashion bloggers in spreading innovations and creations of mixing and matching Muslim fashion to be more attractive. From the fashion bloggers community, a Hijaber community is formed.

The high number of middle-class Muslims in Surakarta city is quite helpful in making Muslim fashion popular. Previously, Muslim fashion was known as fringe, old-fashioned and extreme. One of the factors causing the rapid growth of the Muslim middle-class in Surakarta is the movement to wear hijab as an affirmation of Muslim's identity. In addition, the economic growth that occurred in Surakarta city gives impact on increasing the number of middle-class. As Surakarta city is one of the small cities in Indonesia, the middle-class Muslims there is classified as a pseudo-middle-class. Those refers to groups that are economically financially capable with a consumptive lifestyle. But, in social life, this group still maintains traditional values and holds egalitarian principles. ${ }^{22}$

The fashion industry began to develop in the 1980s. It happened after the issuance of SK 100/D/Kep/C/1991 which indirectly freed Muslim women to dress. This affected the high use of Muslim fashion at that time, because the use of Muslim clothing was no longer restricted. Currently, Muslim fashion is worn from various social classes and ages. Variations in ages and social classes results a high demand for Muslim fashion. It also results of many Muslim fashion brands offering various models of fashion in order to meet Muslim women needs. The high consumptive value of Muslim women in Muslim fashion encourages them to follow the latest Muslim fashion trends. There are even Muslim women who take their time to find out about the development of Muslim fashion by following the hijabs' community, magazines, social media, and so on. In addition, as some of them see the progress of Muslim fashion from some public figures, the existence of public figures is considered to be a trendsetter for Muslim women. Most of them imitate the public figures they admire for actualizing themselves. The main factors that make Muslim women interested in Muslim fashion are including the taste, the comfort, and high-adherent of Muslim women of Sharia.

\footnotetext{
${ }^{22}$ Nurul Aeni dan Lilam Kadarin Nuriyanto, "Religiusitas Kelas Menengah Muslim Surakarta (Interaksi dengan Globalisasi dan Modernisasi)", Jurnal Multikultural \& Multireligius, Vol.19 No.2: 2020, hlm.235-236
} 
1. The existence of Solo Hijabers community in Boosting Muslimah Fashion in Surakarta City

The phenomenon of Muslim fashion progress in Surakarta city cannot be separated from the influence of today's lifestyle related to technology which in turn gives rise to the Muslim community or sermon. The social community has a significant role in shaping Muslim woman's identity. Since a community or group greatly influences its members in behaving, the social community acts a reference group. In Surakarta city, there is one Muslim community that gives a big impact, namely Solo Hijabers community. This community is considered as a community that become a forum and model for Muslim women in Surakarta city.

Solo Hijabers community has several agendas including grand launching as a starting point of this community, and several activities such as gathering member, garage sale, butik les, routine sermon, milad, etc. ${ }^{23}$. Introducing and promoting hijab among young people is the goal of the Solo Hijabers community. The goal of the Solo Hijabers community is to introduce hijab with a fashionable model to young people and to erode the notion that those who wear Muslim fashion are tacky and old-fashioned. ${ }^{24}$ Dian Ayu, a member of Solo Hijabers community, said that the way she dress was inspired by several activities from Solo Hijabers community including hijab tutorial activity which always varied following fashion trends. ${ }^{25}$
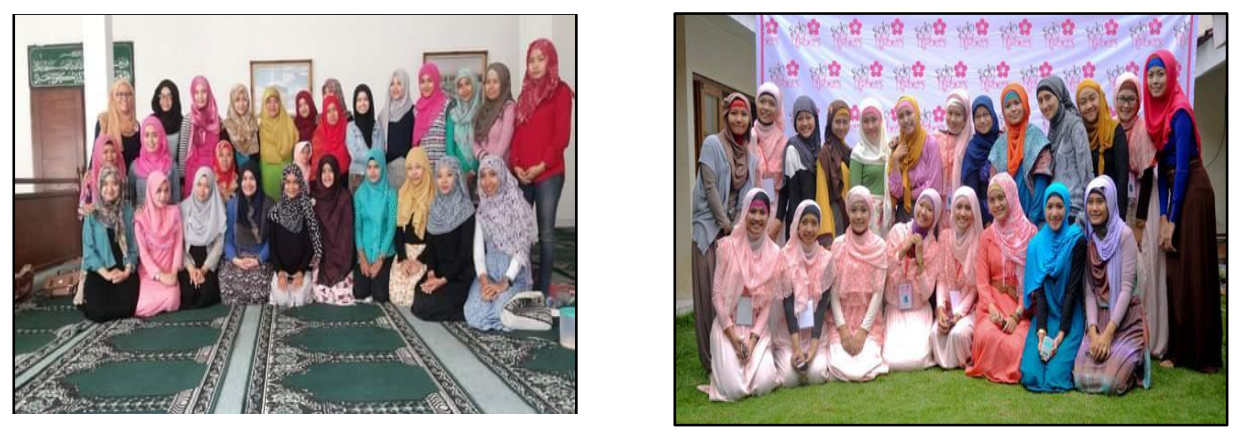

Figure 3. Solo Hijabers' members in 2012

Source: Facebook page of Solo Hijabers community

${ }^{23}$ Alan Sigit Febrianto, Syamsul Bakhri, “Gerakan Sosial Kaum Perempuan Melawan Euphoria Media Melalui Komunitas Hijabers di Kota Surakarta”, Marwah: Jurnal Perempuan, Agama dan Jender, 2018, p. 9

${ }^{24}$ Interview with Mrs Diyah Ayu as committee Solo Hijabers community, at 15 November 2021.

${ }^{25}$ Ibid., 
2. The role of Ikatan Perancang Busana Surakarta (Ikapersata) presenting fashion activities in Surakarta City

Ikatan Perancang Busana Surakarta (Ikapersata) or Surakarta Fashion Designers Association has an important role in introducing the latest fashion trends in Surakarta. It includes batik and Muslim fashion. The inauguration of Ikapersata coincided with an annual event held by the Surakarta City Tourism and Culture Office called Solo Batik Fashion 3 in 2011. As the activity was held to introduce the clothes designed by designers from Surakarta city, it become a forum and place introducing potential in the fashion. ${ }^{26}$ Ikapersata became a forum for introducing designs of local designers in Surakarta city. The Solo Fashion Week event and the appreciation of junior fashion design are initiated by Ikapersata. Solo Fashion Week features fashion designs from Surakarta City designers and others. ${ }^{27}$ Those designers from Surakarta are Robin Karebet, Riani, Titi Meinawati, Owen Joe, Joko widiarto, Uzy Fauziah, Rory Wardana, Astute K, Rizma, Djongko Rahardjo, Andreas Harris, and Ucok Sirait. They presented their designs their own characteristics at the 2014 Moslem Fashion Fiesta at Atrium Solo Paragon Lifestyle Mall on July $142014{ }^{28}$ They offered designs for Muslim women's fashion for Eid al-Fitr. One of them, Riani who had fashion design themed Deewani displayed a combination of black gothic batik with pieces of harajuku clothing and origami techniques. Besides she offered clothing with a wrapped skirt suit combined with a vest made of classic batik equipped with complementary accessories such as a headscarf and boots, a headscarf with pet hat accessories, and puppet necklaces. ${ }^{29}$

\footnotetext{
${ }^{26}$ Solo Pos, "Solo Batik Fashion, Ajang Desainer Daerah Berunjuk Karya” on 16 Juli 2011.

${ }^{27}$ Solo Pos, "Ikapersata siap Gemparkan Solo" on 2 Mei 2010

${ }^{28}$ Solo Pos, "11 Desainer Solo Pamer Karya di Moslem Fashion Fiesta 2014” on 15 Juni 2014, p.1

29 Solo Pos, "Moslem Fashion Fiesta 2014: Ikapersata tawarkan Gaya Idul Fitri 1435 H" on 15 Juni
} 2014, p.1 


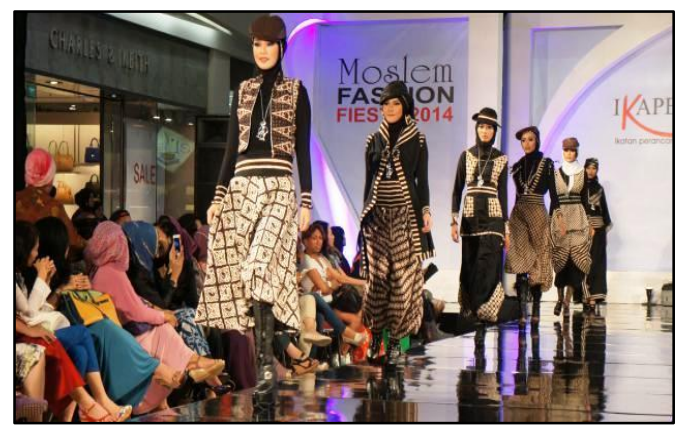

Figure 4. 2014 Moslem Fashion Fiesta

Source: Solo Pos on July 14, 2014

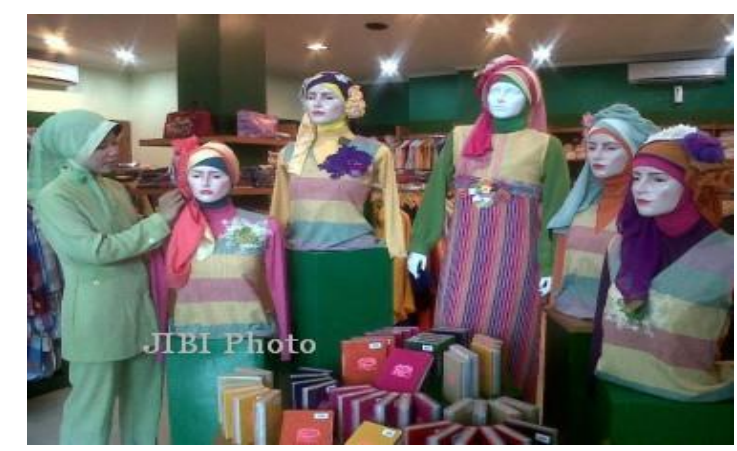

Figure 5. Collection muslimah fashion of al-Fath boutique, Surakarta Source: Solo Pos, 03 March 2013

3. The emerge of shopping centers, boutiques, fashion houses in Surakarta City The potential for Muslim fashion in Surakarta City is quite high considering Surakarta city related to textile industry including batik. The existence of shopping centers and boutiques is a proof that fashion progress in Surakarta city. In Surakarta city, there are some shopping centers which are quite emerging such as Fashion Houses, and Boutiques.In Surakarta city, there are several shopping centers including Solo Square, Solo Grand Mall, Paragon Mall, Klewer Market, Solo Wholesale Center, Beteng Trade Center. Some of Fashion Houses in Surakarta include Bilqis, House of Danar Hadi, al-Fath, etc. The emerge of shopping centers, boutiques, and clothing stores shows how the fashion industry in Surakarta performing quite in demand. The number of shopping center facilities in Surakarta City certainly sees the high public interest in fashion clothing needs including Muslim fashion.

The famous shopping center in Surakarta City is Pasar Klewer or Klewer Market. It is such a proof of the high needs of the community. The needs for clothing is no exception. Pasar Klewer is one of the tourism assets and Solo's self-image as a part of the Solo community and not limited to economic activities. This market, located next to the Surakarta Palace, is characterized as a traditional market that trades a varied textile which. Pasar Klewer always presents an up-to-date and trendy fashion. A consideration comes related with whether it is comfortably and appropriate to wear with the Muslim itself. It comes also for Muslim fashion with 
varied models every year. However, the main factor in choosing Muslim fashion is comfortable and of course trendy. ${ }^{30}$

The existence of mass media certainly helps in introducing Muslim fashion to the community resulting a great demand. It is shown in Solo Pos newspaper which has a special rubric discussing about Mode Pekan Ini. This rubric on January $5^{\text {th }}, 1999$ edition discussed how to look fashionable with Muslim fashion. Here, Muslim women can look more fashionable with dresses by Al-Fath Solo. ${ }^{31}$

The Muslim fashion business has become significant in Surakarta City. Designers compete with each other in presenting creative and innovative designs. The most influential Muslim fashion house in Surakarta is al-Fath. Al-Fath boutique is a boutique founded in 1989 in Yogyakarta. This branch in Surakarta was established in the 1990s after the establishment of al-Fath Yogyakarta. It was because of the large number of Muslim communities in Surakarta City. This boutique, carrying one stock Muslim shopping theme, serve an easy alternative for finding Muslim equipment in Surakarta including Muslim fashion ${ }^{32}$ Fashion products with embroidery are one of the characteristics of Rumah Aulia, which is located on Jl. Dr. Radjiman 206, Surakarta City. Embroidery techniques are also applied to Muslim fashion. The color gradation technique become the creation of Rumah Aulia in presenting embroidered clothing with a new image that used to be an old-fashioned technique. The latest embroidery application is applied in the waist, chest and between the opnaisel (pleated). Embroidery with flowers and sequins can be applied to a two-piece dress with chiffon details and unfinished on the edges. ${ }^{33}$

\footnotetext{
${ }^{30}$ Interview with Mrs Tini on Tuesday,06 April 2021 at 11.30 at Pasar Klewer, Surakarta.

${ }^{31}$ Solo Pos. "Tampil Modis dengan Busana Muslim" on 4 Januari 1999, p. 12

32 Interview with Mrs. Dewinta on Wednesday 14 April 2021 at al-Fath Boutique at Jl.Slamet Riyadi
} No. 23, Kec. Ps. Kliwon, Surakarta.

${ }^{33}$ Solo Pos, "Bordir, Bikin Tampil Menawan" on 16 Juni 2012. 


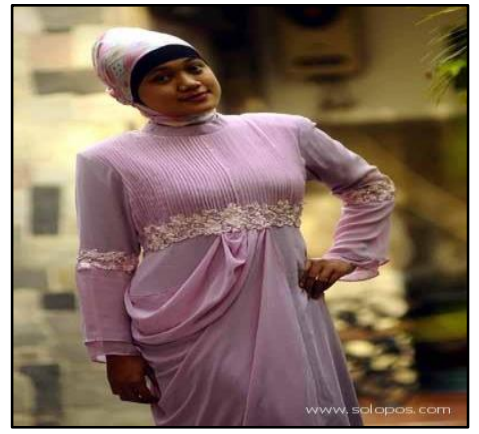

Figure 6. Embroidery Techniques from Rumah Aulia Boutique, Surakarta

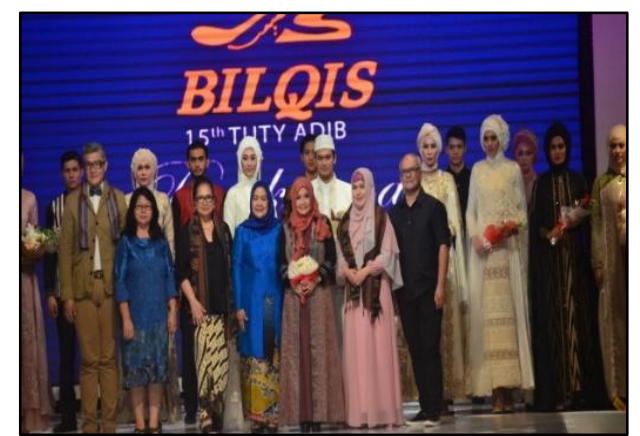

Figure 7. Tuty Adib's design in Tuty Adib's show

Source: Okezone, 21 November 2015

Source: Solo Pos, 2012

Tuty Adib, a fashion designer, established Bilqis by Tuty Adib in Surakarta City in 2000 which later opened a branch in Jakarta. ${ }^{34}$ The clothes designed by Tuty Adib have the characteristics of being fashionable, feminist, classic, and elegant. At the beginning, she designed clothing with hijab and loose clothes. Further, it began to appear robes or dresses equipped with accessories such as handmade sequins and hijab with papandanan, then later in the form of long blouses such as tunics combined with loose pants. Tuty Adib tries to present a feminism-and-classsic clothes with a touch of cutting lines, by creating creations in folds, simple and lean cuts. Tuty Adib's design continues to prioritize Islamic sharia. As Muslim fashion should be, the design must pay attention to fabrics that do not see-through, not show the curves of the body, and not resemble men. Therefore, Bilqis presents feminist, classic, and elegant fashion. ${ }^{35}$

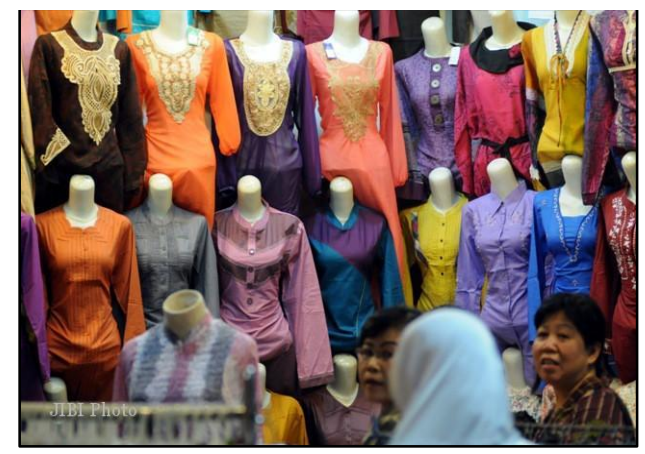

Figure 8.

Collection of Muslimah Fashion at PGS

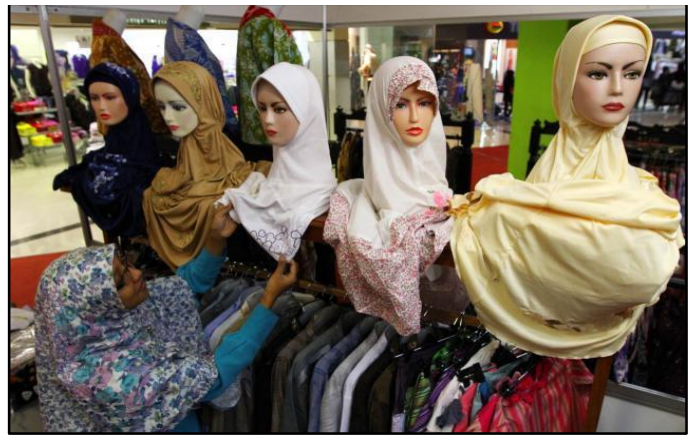

Figure 9.

Muslimah Collection at Made Fesyen store

\footnotetext{
${ }^{34}$ Interview with Mrs. Yuliana as the secretary of Mrs Tuty Adib on 7 April 2021 in Bilqis Workshop at Jln. Pakel No.9, Laweyan, Surakarta City.

${ }^{35} \mathrm{Ibid}$,
} 
Looking at the collection of Muslim fashion at Pusat Grosir Solo (PGS) in 2012, it featured various forms of Muslim fashion, including blouses, tunics, and robes with embroidery and coincided with fashion booming of the Rumah Aulia boutique with its embroidery technique. This indicates that Muslim women in Surakarta City responded very quickly to the progress of Muslim clothing. In addition, Muslim fashion models are very easy to find in Surakarta city. There are several Muslim fashion shops around Universitas Muhammadiyah Surakarta (UMS) selling Muslim fashion at affordable prices. One of them is the Made Fesyen store, which has a collection of Muslim fashion that is produced by itself or buy the product at Pasar Klewer and Tanah Abang markets. The products including a syar'i robe with a long and loose hijab suit, a Cita-Citata-style robe using a combination of chiffon and jersey material, a Nagita-style robe which has a fashion model with slits on its sleeves and a Najwa-style hijab in opera Cinta di Taj. Mahal are the best-selling products trending in 2015. The progress of Muslim fashion in Surakarta city quickly spread widely. Surakarta city, as a textile shopping center in Indonesia, is one of the factors for Muslim women for being up-to-date on the progress of Muslim fashion in Indonesia and especially in Surakarta city.

Seeing the progress of Muslim fashion was originally a traditional dress or kebaya with a veil that only draped over the head. Now Muslim fashion comes with various shapes, colors, variations and materials. As for the progress of Muslim fashion in Surakarta city, such as the picture attached to the picture of the recreational activities of Al-Islam High School students and UNS scientific writing activities in the form of simple clothes in the form of blouses and pants combined with a hijab tied to the neck. In its progress, fashion show activities and the election of Muslim women in Surakarta began. The existence of boutiques and fashion houses in Surakarta city plays an important role in the progress of creative and innovative fashion in Surakarta city. For example, al-Fath boutique continues to develop its innovations by looking at the market interest. Moreover, the Bilqis boutique, which was founded in 2000, has a classic elegant fashion theme. Tuty Adib as the owner tries to eliminate the notion that Muslim women's fashion is out-to-date, plain, and 
simple. The embroidery creation pioneered by Aulia's home boutique is one of the innovations that makes Muslim clothing diverse in its progress.

of Muslim fashion. The increasing number of attractive fashion models requires Surakarta Muslim women to be more up-to-date. Most models or styles of Muslim fashion worn by Muslim women in Surakarta city follow the progress of Muslim fashion in Indonesia. For example, the Muslim fashion collection of Made Fesyen store presented clothes that were popular in 2015 such as the Cita-citata-style robe, the Nagita-style robe, and the Najwa-style hijab, because Made Fesyen was sold at Tanah Abang Market and Pasar Klewer. In addition, the hijab tutorial activity organized by Solo Hijabers in 2012 featured varied colour and style. The tutorial was in accordance with popular hijabs in 2012, introduced by Indonesian designer Dian Pelangi with a more colorful and contemporary image of fashion. The rest are Muslim women who wear Muslim fashion based on the orders and rules of the socio-religious organization they join with. There are several religious organizations that have provisions for Muslim women's fashion as a characteristic of these organizations.

\section{CONCLUSION}

Based on the explanation above, it can be concluded that there are several factors causing Muslim women's fashion to be widely known by Muslim women in Surakarta, including the occurrence of Islamization in Surakarta City during the New Order which cannot be separated from the socio-political conditions of the Surakarta people, especially the G30S/PKI incident. The event resulted chaos and needed a way to restore the condition of Surakarta City. Restoration was carried out through political actions. Religion was also used as an instrument to restore security and order. The spread of Ikhwanul Muslimin and the occurrence of the Iranian Revolution became factors for Muslim women's fashion to be widely known in Surakarta city, because the transnational thought thrived in academic sectors was enough to influence students including students at Sebelas Maret University (UNS). The Hijab "Islamization" movement was a movement that was quite intensively carried out among students or on campus. The momentum of the issuance of SK 100 $\mathrm{D} / \mathrm{Kep} / \mathrm{C} / 1991$ which allowed schoolgirls to wear hijab, indirectly gave Muslim women freedom to wear Muslim clothes. 
The progress of Muslim fashion in Surakarta city cannot be separated from the progress of Muslim fashion in Indonesia. However, the high interest of Muslim women in Surakarta has resulted in very rapid progress of Muslim fashion. Moreover, it is supported by facilities such as shopping centers, boutiques, fashion houses, and Muslim fashion shops that are emerging in Surakarta City. The existence of Solo Hijabers and Ikapersata (Surakarta Fashion Designers Association) is one of the external factors for Muslim clothing to experience rapid progress. Both of them play role in introducing Surakarta Muslim women about Muslim fashion in Indonesia. For example, al-fath boutique issued the Rainbow Fest theme in 2012. This period was one of the momentums for the progress of colorful Muslim women's fashion with complex and diverse shapes as introduced by Dian Pelangi as a designer.

\section{REFERENCES}

Aeni, Nurul dan Lilam Kadarin Nuriyanto, "Religiusitas Kelas Menengah Muslim Surakarta (Interaksi dengan Globalisasi dan Modernisasi)", Jurnal Multikultural \& Multireligius, Vol.19 No.2: 2020

Daliman, "Metodologi Penelitian Sejarah", (Yogyakarta, Penerbit Ombak: 2021)

Damayanti, Sri Ika, "Perkembangan Desain Busana Muslim dalam Tinjauan Sosiologis", CORAK: Jurnal Seni Karya Vol.3 No.1:2014

Darmawijaya, "Islam dan Orde Baru: Membaca Kembali Politik de-Islamisasi Soeharto", Sosiologi Reflektif, Vol. 10, No.1, November 2015.

Dinas Kependudukan dan Pencatatan Sipil Kota Surakarta, "Profil Perkembangan Kependudukan Kota Surakarta Tahun 2018,

Fahrizal, Adif “Bulan Bintang dan Salib di Kota Bengawan, Islamisasi, Kristenisasi, dan Hubungan Muslim-Kristen di Surakarta (1966-2000)", Thesis (Yogyakarta, Universitas Gadjah Mada: 2015)

Febrianto, Alan Sigit dan Syamsul Bakhri, "Gerakan Sosial Kaum Perempuan Melawan Euphoria Media Melalui Komunitas Hijabers di Kota Surakarta”, Marwah: Jurnal Perempuan, Agama dan Jender, 2018

Hanifah, Pocut (28 desember 2015), Fenomena Jilbab, accesed on Islamlib.com on 7 Desember 2019.

Kesuma, Septa Jilbab dan Reproduksi Identitas Mahasiswi Muslimah di Ruang Publik, MUKADIMAH: Jurnal Pendidikan, Sejarah, dan Ilmu-ilmu Sosial, Vol.1, No. 2, Februari 2018

Kompas, "Resmi Berlaku, Penggunaan Seragam Khas di Sekolah” on 17 Februari 1991 
Maharani Nur Afifah, (15 Juni 2014), "Moslem Fashion Fiesta 2014: Ikapersata tawarkan Gaya Idul Fitri 1435 H”, Koran Solopos

Mahardini Nur Afifah, (4 September 2015), “Aktivitas Ibu Negara: Didampingi kahiyang dan Selvi, Iriana Jokowi Hadiri Halal Bi Halal Muslimah Solo”, Koran Solopos.

Ricklefs, Merle Calvin “Mengislamkan Jawa”, trans. FX Dono Sunardi \& Santrio Wahono, (Jakarta, Serambi Ilmu Semesta: 2013)

Ruslan, Faryda "Politik Hukum Islam Masa Orde Baru Dan Produk PerundangUndangannya", Al Qisthas: Jurnal Hukum dan Politik, Vol.10, No.2, 2019

Soebagiyo, Daryono dan M. Wahyudi, “Analisis Kompetensi Produk Unggulan Daerah Pada Batik Tulis dan Cap Solo Di Dati 11 Kota Surakarta", Jurnal Ekonomi Pembangunan, Vol.9, No.2, 2008

Solo Pos, "Bermula Dagangan di Pundak Kleweran" on 13 Oktober 1997

Solo Pos, "Bordir, Bikin Tampil Menawan” on 16 Juni 2012.

Solo Pos, "Ikapersata siap Gemparkan Solo" on 2 Mei 2010

Solo Pos, "Info Belanja: Inilah Toko Busana Muslim dengan Harga Mahasiswa", on 8 Juli 2015

Solo Pos, "Mesjid Agung \& Studio Model gelar Lomba Busana Muslim (Perebutkan Trofi Ketua Bhayangkari)" on 5 Januari 1999

Solo Pos, "Solo Batik Fashion, Ajang Desainer Daerah Berunjuk Karya” on 16 Juli 2011

Solo Pos. "2013 Al-Fath target penjualan tumbuh 20\%”, on 03 Maret 2013

Solo Pos. “Tampil Modis dengan Busana Muslim”, edisi 4 Januari 1999

Sunaryo Haryo Bayu, (15 Juni 2014), "11 Desainer Solo Pamer Karya di Moslem Fashion Fiesta 2014”, Koran Solopos

Warta Exspor Industri Muslim 2015, Kementrian Perdagangan Republik Indonesia, 2015

Wibowo, Arif disampaikan pada kuliah tamu : "Gerakan Dakwah Kampus di Universitas Sebelas Maret Surakarta”, pada tanggal 29 November 2018. 
Factors of Muslim Fashion Progress In Surakarta City...(Laela Puji Utami) 